\title{
A liberdade em $A$ montanha mágica
}

\author{
[Freedom in The magic mountain] \\ http://dx.doi.org/10.11606/1982-883723401
}

Thiago Henrique de Camargo Abrahão ${ }^{1}$

\begin{abstract}
Amid the hilly landscape of the Swiss Alps, a sanatorium for respiratory diseases. The many coughs in long treatment do not have more serious commitments than following the usual mealtime and home schedule. Faced with this spatially stagnant and temporally hermetic medium of Thomas Mann's The magic mountain, freedom is muffled. We do not refer, of course, to the creative freedom of the German author, whose proof of grandeur is the novel itself, neither to the interpretative freedom of the reader, but to freedom -or rather its attenuation- problematized by the characters of this long history. This is the case of the young protagonist Hans Castorp, whose learning about the theme paradoxically occurs at the time of his stay in a place that hijacks his freedom. This is not only because the main character is unable to choose, without constraints, the values that underlie his choices, but also because this is hampered by the anomalous, or, according to the title, "magic" spatio-temporal situation of the mountain. How this problem is presented narratively, by means of some freedom indexes - that is, elements that modify the indeterminacy of the narrative, for the characters and the reader-, is what we want to present.
\end{abstract}

Keywords: literary theory; freedom; The magic mountain.

Resumo: Em meio à paisagem montanhosa dos Alpes suíços, um sanatório para doenças respiratórias. As muitas tosses ali em longo tratamento não possuem compromissos mais sérios que não sejam seguir o horário habitual das refeições e dos repousos. Diante desse meio espacialmente estagnado e temporalmente hermético de A montanha mágica, de Thomas Mann, a liberdade mostra-se amortecida. Não nos referimos, evidentemente, à liberdade criativa do autor alemão, cuja prova de grandeza é o romance em si, tampouco à liberdade interpretativa do leitor, mas à liberdade - ou, antes, sua atenuação - problematizada pelas personagens dessa longa história. É o caso do jovem protagonista Hans Castorp, cujo aprendizado a respeito do tema paradoxalmente ocorre durante sua estada num lugar que sequestra sua liberdade. Isso se dá não apenas porque a personagem principal é incapaz de eleger, sem constrangimentos, os valores que embasam suas escolhas, mas também porque isso é dificultado pela situação espaçotemporal anômala ou, segundo o título, "mágica" da montanha. Como essa problemática é apresentada narrativamente, por meio de alguns índices de liberdade - ou seja, elementos que modificam, para as personagens e para o leitor, a indeterminação da narrativa -, é o que queremos apresentar.

Palavras-chave: teoria literária; liberdade; A montanha mágica.

\footnotetext{
${ }^{1}$ Universidade Estadual Paulista "Júlio de Mesquita Filho", Rua Cristóvão Colombo, 2265, Jardim Nazareth, São José do Rio Preto, SP, 15054-000, Brasil. E-mail: thabrahao@ outlook.com. ORCID: 00000001-5137-6655
}

\section{(cc) BY-NC}

Pandaemonium, São Paulo, v. 23, n. 40, mai.-ago. 2020, p. 1-19 
No início do século XX a humanidade assistiu à derrocada traumática da razão, cuja causa, desnecessário dizer, refere-se, dentre outros motivos, aos grandes avanços técnico-científicos, à quebra de paradigmas no campo das humanidades, ao progresso das comunicações e dos transportes, aos momentos de crise geopolítica e suas consequências bélicas. Nesse e em outros meios, enquanto importante barômetro das contradições histórico-sociais, a literatura participaria, com suas palavras ou com seus silêncios, da compreensão do homem no mundo e do mundo no homem.

Isso seria possível porque qualquer fazer artístico, como qualquer realização cultural, está situado no tempo e no espaço e contribui para a formação de nossa subjetividade, integrando, portanto, o que há de humano no ser. Não por acaso, manifestações literárias como as oriundas do período modernista no campo romanesco provam que as inovações quanto à técnica narrativa - a fragmentação do sujeito, o fluxo de consciência, o tratamento subjetivo do tempo etc. - em alguma medida acompanham as transformações históricas em relação às quais o ser humano é (e está) sujeito. Não se trataria, evidentemente, de uma relação determinista, mas de uma influência recíproca entre a literatura (ou, de forma geral, a arte) e a existência humana - influência que será maior ou menor a depender do modo como o homem compreende sua existência e a expressão desta, artisticamente ou não. Nesse sentido, observamos que em contextos de exceção a resposta dada pela arte evidencia uma influência recíproca, cujo valor estético e também ético é fundamental para as ciências humanas e, por maior razão, para a humanidade.

Autores como Thomas Mann (1875-1955) ilustram esse fenômeno. Ao viver num dos períodos mais complexos e turbulentos da história europeia, com o registro de duas guerras mundiais cujo protagonismo germânico se deu no pior e mais hediondo dos sentidos, o escritor alemão registrou em sua literatura a relatividade do tempo e do espaço, a crise do sujeito, as contradições da história. Ora, se todo artista "é parte de um todo histórico e social maior"2 (LUKÁCS 1969: 54), Mann soube fazer disso o pano de fundo de suas obras, passando de uma posição conservadora, ao longo da Primeira Guerra Mundial, para um engajamento humanista posterior, em defesa da República de Weimar - regime político estabelecido na Alemanha entre 1919 e 1933, tratando-se de uma democracia representativa semipresidencial -, e, já no período da Segunda Guerra

\footnotetext{
2 "He [the artist] is part of a larger social and historical whole." As traduções deste estudo são de minha responsabilidade.
}

Pandaemonium, São Paulo, v. 23, n. 40, mai.-ago. 2020, p. 1-19 
Mundial, contrariamente ao regime nacional-socialista alemão. Tais manifestações públicas de um intelectual em defesa de suas ideias políticas, antes de comprometerem a arte de Mann, serviram-lhe como incitação para a procura de novas formas de narrar e de representar os movimentos e as contradições históricas de um mundo em crise desde o fim do século XIX. Como se verifica, "[a] literatura permite a Thomas Mann afirmar a liberdade, bem como a sua liberdade. Sua liberdade [...] mediante as perseguições e o exílio, a despeito da proibição de que seus livros são objeto" (DAYAN-HERZBRUN 1997: 80).

Para além de ensaios como Considerações de um apolítico (1918) e O problema da liberdade (1939), a produção romanesca de Mann é extensa, e nela podemos encontrar a mesma preocupação do autor para com sua época e sua arte. São obras, em suma, que definem o que é a arte literária para o escritor alemão, “"estas brincadeiras muito sérias', uma vez disse Goethe sobre o seu Fausto, e isso é a definição de toda arte, incluindo $A$ montanha mágica". E completa: "Mas eu não poderia ter feito piada e brincado sem antes ter vivido em uma humanidade sangrenta, sobre a qual me criei como artista livre"3 (MANN 1958: 12-13). Livre, apesar da perseguição e do exílio, Mann soube ver na arte o que ela é: um dos melhores meios para falar sobre a liberdade, pois esta quase se confunde com as próprias atividades criadora e leitora, para as quais ou a imaginação é tudo ou é pouco. Isso se dá porque a liberdade, como aqui a entendemos, diz respeito não apenas à possibilidade humana de fazer escolhas, mas sobretudo à possibilidade de escolher os valores que embasam tais escolhas, bem como à consciência intersubjetiva de suas implicações.

É o caso d'A montanha mágica - obra em que estão em jogo não apenas a saúde física da personagem, mas especialmente sua condição existencial -, ou, dentre outros, Doutor Fausto (MANN 1947), narrativa que, por meio da vida do músico Adrian Leverkühn, faz um paralelo artístico e filosófico com o contexto histórico-social europeu, sublinhando o caráter nulo de um fazer artístico quase solipsista, pouco disposto ou incapaz de considerar a importância do mundo exterior para a formação da vida interior dos indivíduos (e também o contrário). Assim, pela tragédia de seu protagonista podemos acompanhar a tragédia da própria sociedade europeia em meio a uma deterioração ética e

\footnotetext{
3 “»Diese sehr ernsten Scherze«, so spricht Goethe einmal von seinem Faust, und es ist dir Definition aller Kunst, auch des »Zauberbergs«. Aber ich hätte nicht scherzen und spielen können, ohne vorher seine Problematik in blutiger Menschlichkeit durchlebt zu haben, über die ich mich dann als freier Künstler erhob."
}

Pandaemonium, São Paulo, v. 23, n. 40, mai.-ago. 2020, p. 1-19 
estética da nação alemã. N'A montanha mágica há algo análogo, visto que "a elevação da montanha, em algum momento um símbolo da arte pura, agora é o símbolo daquele divórcio da arte em relação às realidades, principal característica social da arte alemã desde o classicismo de Weimar"4 (REED 1974: 272). Em Mann lemos as palavras de um escritor comprometido não apenas com a liberdade da técnica narrativa, mas, de igual modo, com a liberdade tout court, procurada e protegida por ser possibilidade de resposta ao homem como questão. Em lugar do divórcio da arte em relação à realidade, temos um compromisso a ser realizado a partir de uma exploração artística e original do mundo, capaz de sugerir as contradições e os conflitos da subjetividade humana por meio do próprio desafio técnico de transformá-la em narrativa.

Como A montanha mágica, muitas das obras de Mann se coadunam com o movimento modernista, cujas transformações profundas instituídas pela inovação formal seguem o radicalismo próprio de uma época conflitante, embora afoita por entender sua natureza. Se “[o] romance não é só mimese do mundo moderno mas também se pôs como seu instrumento cognitivo privilegiado" (MAGRIS 2009: 1026), a obra romanesca de Mann é moderna, dentre outros aspectos, por sua tentativa de romper com o passado e, vinculando-se ao presente, de questionar o futuro. Vemos, por conseguinte, que sua criação literária não comporta tão somente o âmbito da estética, mas se aproxima da ética ao apresentar perspectivas críticas para um mundo de ruptura e de valores em colapso. Ao escrever sob o viés de um realismo que soube explorar o "duplo processo - de simultânea afirmação e negação - da autonomia individual" (COUTINHO 2005: 89), o autor alemão conseguiu, como poucos, incitar a liberdade em prol de uma releitura crítica do mundo, e, nesse sentido, para o teórico húngaro Georg Lukács (1979: 58), “o que é real, ele seguirá até as raízes, mas nunca antecipará o futuro"

Ora, é o que temos n'A montanha mágica, narrativa sobre "um jovem singelo [que] viajava, em pleno verão, de Hamburgo, sua cidade natal, a Davos-Platz, no cantão dos Grisões. Ia de visita, por três semanas” (MANN 2016: 13). Trata-se de Hans Castorp, jovem engenheiro naval alemão que visita o primo Joachim Ziemßen no Sanatório Internacional de Berghof, na Suíça, destinado ao tratamento de doenças respiratórias. Apesar da aparente simplicidade do enredo, são complexos os temas colocados em

\footnotetext{
4 "The elevation of the mountain, sometime symbol of pure art, is now the symbol of that divorcing of art from realities which has been the chief social characteristic of German art since the age of Weimar Classicism."

5 "What is real he will follow to the roots, but he will never anticipate the future."
}

Pandaemonium, São Paulo, v. 23, n. 40, mai.-ago. 2020, p. 1-19 
discussão. As três semanas que durariam a visita ao primo transformam-se em sete anos, ao longo dos quais o protagonista se afasta da planície (a representar o mundo humano em sua totalidade) para se embrenhar em descobertas existenciais. Castorp distancia-se, pois, da família, dos amigos, da sociedade, da história, de suas ideias sobre o tempo, a morte, o amor. Ao fim, com o advento da Primeira Guerra Mundial, o jovem consegue finalmente voltar para a planície, engajado às fileiras do exército.

Para o contexto modernista, o livro é um marco por suas experimentações técnicas (mormente em relação ao tempo e ao espaço), mas não apenas: para o próprio autor, tratase de um momento de mudança. A redação do romance levou doze anos, tendo início em 1912, sendo interrompida em 1915, retomada em 1919 e concluída em 1924, quando de sua publicação. Em meio à criação artística, a violência histórica da Primeira Guerra Mundial levou Mann a mudar de posicionamento político e passar a ser, posteriormente, um símbolo da literatura, da Alemanha, da liberdade, pois o autor alemão fez valer o que é próprio tanto para a arte como para a existência, a saber, a autonomia humana de criar seus próprios valores. Não por acaso, A montanha mágica deveria ser lida, segundo o autor, como "um documento da constituição da alma europeia e da problemática intelectual do primeiro terço do século XX"6 (MANN 1958: 7). De modo similar à "montanha mágica do Olimpo" - que representaria, para Friedrich Nietzsche (1999: 36), a saída encontrada pelo homem grego diante dos "temores e os horrores do existir" -, a montanha mágica de Mann também sugere medos e horrores, os quais Hans Castorp conhecerá, a despeito de sua atitude de estupor diante da revelação sobre o que é a vida, a liberdade, a morte. Todavia, a similaridade termina aí, pois as descobertas do protagonista não se darão por meio de deuses e de dogmas, como o fazem os sistemas mítico-religiosos, mas por meio de homens e de ideias, fator que, escusado dizê-lo, estabelece uma diferença radical, pois um deus como o cristão, na hipótese de existir e de outorgar o livre-arbítrio ao homem, estaria consequentemente eximido da responsabilidade para com as ações humanas.

Quanto ao homem, com deus ou sem deus, não há subterfúgio (eticamente) possível para negar a sua responsabilidade no âmbito do mundo cultural que criou e no qual vive, embora a montanha suíça possa permitir a Hans Castorp refletir sobre si e o mundo no isolamento geográfico do sanatório, distanciado da planície mas a observando

\footnotetext{
6 "ein Dokument der europäischen Seelenverfassung und geistigen Problematik im ersten Drittel des zwanzigsten Jahrhunderts".

Pandaemonium, São Paulo, v. 23, n. 40, mai.-ago. 2020, p. 1-19
} 
criticamente: “A atmosfera, lá embaixo, é cruel, é inexorável. Quando alguém está deitado como eu, e olha as coisas de longe, sente-se horrorizado" (MANN 2016: 230). O protagonista envolve-se concreta e abstratamente com o espaço em que se encontra, relacionando-se com a montanha de modo significativo. Em se tratando do espaço interior, em meio a indivíduos de diversas nacionalidades, como alemães, ingleses, russos, mexicanos, o sanatório é um microcosmo cuja estrutura pode ser evidenciada na distribuição das personagens entre as sete grandes mesas da sala de refeições, o que forma um mosaico social em meio a uma atmosfera de transcendência espaçotemporal, acima das épocas e das civilizações - mas as representando muito bem, mesmo porque "[o] homem não vive somente sua vida pessoal como indivíduo; consciente ou inconscientemente, participa também da vida de sua época e de seus contemporâneos" (MANN 2016: 44).

No que concerne ao espaço exterior do sanatório de Berghof, a começar pelo regime climático, segundo o primo Joachim, "temos dias de verão e dias de inverno, dias de primavera e dias de outono, mas não há propriamente estações aqui em cima" (MANN 2016: 113). Note-se, pois, que uma marcação do tempo oriunda de estações do ano dá espaço a uma indefinição climática, cujas repentinas mudanças resultam no reforço da desorientação espaçotemporal que atinge a percepção dos internos. O espaço físico, por sua vez, é rasgado por formas montanhosas, maciços nevados cujas imediações serão conhecidas por Hans Castorp quando de seus passeios para além das cercanias do sanatório. O principal deles, pelo que representou para o protagonista, é narrado no célebre subcapítulo "Neve", em que, como sugeriu Paul Ricœur (1995: 219-220, grifo no original), "[a] montanha devastada pela neve é [...] o equivalente espacial da própria experiência temporal". Nesse subcapítulo, o mundo objetivo, em que impera a causalidade, se coloca como a contraparte do mundo subjetivo, em que prevalece a liberdade: Hans Castorp, em meio à nevasca indiferente a ele, não pode, contudo, ser indiferente a ela, e segue esquiando em seu passeio, ignorando premeditadamente os perigos daquele ambiente inóspito.

Sentiu satisfação ao perceber sua independência alada, a liberdade de suas andanças. Não tinha à sua frente nenhum caminho que se visse obrigado a seguir; tampouco atrás dele havia um que o levasse ao ponto de partida. A princípio, encontrara sinais, paus cravados no solo, sinais da neve, mas de propósito libertara-se da sua influência, que lhe recordava o homem da corneta e que lhe parecia em desacordo com a relação íntima entre ele e o grande ermo hibernal. (MANN 2016: 552) 
Todavia, o que o narrador confunde com a liberdade do protagonista é, na verdade, seu oposto. Afora o ato inconsequente de se embrenhar na nevasca, o que deixa patente a ignorância (consciente ou não) da personagem quanto às consequências irresponsáveis de suas ações, com a estagnação do tempo, do espaço e, consequentemente, da causalidade - elementos que compõem a estrutura do âmbito natural -, a liberdade também se estagna, diminuindo para o homem, como já indicamos, as escolhas possíveis onde é lenta percepção da conexão de responsabilidade existente entre ações e consequências. Ora, escolhas pautadas tanto no eterno como no efêmero amainam a liberdade, pois afastam (ou aproximam) em demasia os atos de seus efeitos, as liberdades de suas responsabilidades, dissociando-as. Em subcapítulo anterior, "Sopa eterna e clareza repentina”, Hans Castorp já começa a perceber tal estagnação espaçotemporal:

Por enquanto basta que todos se lembrem da rapidez com que decorre uma "longa" série de dias para o doente que os passa acamado. É o mesmo dia que se repete uma e outra vez; mas, justamente por se tratar sempre do mesmo dia, parece no fundo pouco adequado o termo "repetição"; melhor seria falar de monotonia, de um agora que parou ou de eternidade. Trazem a sopa até você na hora do almoço, assim como a trouxeram ontem e a trarão amanhã. E ao mesmo tempo você se sente presa de uma sensação singular que vem não se sabe de onde nem por quê: você se vê invadido por uma espécie de vertigem, enquanto a sopa se aproxima; os tempos confundem-se, misturam-se no seu espírito, e o que se revela a você como verdadeira forma da existência é um presente sem extensão, no qual lhe trazem a sopa eternamente. (MANN 2016: 213-214, grifos meus)

Por conseguinte, as personagens habituadas ao que há de mágico no sanatório “assegurava[m], em troca da renúncia aos prazeres e às atribuições da humanidade dos países planos, uma existência inerte, sem dúvida, mas sumamente fácil e divertida, despreocupada até a abolição do tempo" (MANN 2016: 539, grifos meus). Dentre tais aspectos, a liberdade abandonada pelos internos - de modo que não se sustenta, então, a tese de Harald Vogel (1970: 71) segundo a qual Hans Castorp permanece, ao longo de sua estada, numa situação de liberdade. O distanciamento do protagonista em relação à planície e seu complexo apego pelo sanatório não fazem dele alguém livre, pois o que há de mágico na montanha é sua capacidade de relativizar o tempo e o espaço e significá-los a seu lento e hermético modo. Há, pois, uma percepção de distanciamento (causado pela sensação de lentidão do tempo) entre causas e efeitos, entre escolhas e responsabilidades - afinal, como alerta a personagem Lodovico Settembrini, "ignoramos a semana como medida de tempo. Para nós, a menor unidade é o mês" (MANN 2016: 72). Ora, torna-se humanamente mais difícil perceber quais serão as consequências de nossas ações quanto mais tais consequências estiverem apartadas de suas causas. Nesse sentido, se considerarmos o aprendizado da liberdade como a apreensão do fato de que ela tem valor 
apenas quando vista como uma moeda cuja outra face apresenta a responsabilidade, ou seja, o efeito de nossas escolhas e ações, então disso se segue o paradoxo: Hans Castorp toma conhecimento do que é a liberdade exatamente num lugar onde ela está atenuada simbolicamente.

Mas não apenas, pois esse enfraquecimento da liberdade é intensificado pela própria estrutura do romance. O primeiro dia passa lentamente para o protagonista - "Meu Deus! É ainda o primeiro dia? Já me parece que estou aqui há muito, muito tempo...” (MANN 2016: 100) -, ainda ligado à percepção de tempo da planície, e analogamente para o leitor, que acompanha em torno de cem páginas de narrativa sobre um único dia. A partir desse artifício técnico, as três primeiras semanas de estada do protagonista são descritas com detalhamento, enquanto que as três próximas semanas não recebem a mesma atenção descritiva. Como esclarece a voz narratorial,

isso poderia causar espanto; e todavia está bem assim, corresponde às leis do narrar e do ouvir. Pois está bem e corresponde às ditas leis que o tempo se torne para nós tão longo ou tão curto que ele se afigure tão vasto ou tão reduzido à nossa experiência quanto o é para o jovem Hans Castorp, o herói de nossa história, requisitado pelo destino de modo tão inesperado. (MANN 2016: 213)

Tal fenômeno prossegue até termos, no espaço de uma página, a narração das seis semanas que antecedem o Natal. Além disso, a voz narratorial investe abertamente na discussão sobre sua função de narrar em relação ao tempo:

Pode-se narrar o tempo, ele próprio, o tempo como tal, em si mesmo? Não, de fato não, algo assim seria um arrojo insano! Ante uma narrativa que rezasse: "O tempo decorria, escoava, seguia seu curso" e assim por diante - não haveria quem, de sã consciência, pudesse chamá-la de narrativa. Seria como se alguém tivesse a ideia maluca de manter durante uma hora um e mesmo tom ou acorde e tomasse algo assim por música. Pois a narrativa se parece com a música, no sentido de, como esta, preencher o tempo [...]. (MANN 2016: 622, grifo no original)

A própria narração, portanto, representa-se como uma experiência própria do tempo, de modo que, por meio desse processo de assimetria do andamento narrativo, o jovem começa a modificar sua percepção temporal, o que confere a Hans Castorp a ilusão, possível apenas naquele ambiente hermético, de reorganizar sua consciência a fim de existir independentemente do tempo histórico da planície, ou seja, de nosso tempo, monopolizado pela "realidade cotidiana burguesa"7 (LUKÁCs 1979: 82). Em Berghof, os pacientes, afinal, devem se preocupar apenas com a morte, ignorando, por conseguinte, a realidade pragmática e responsável das cidades, bem como os próprios valores que

\footnotetext{
7 "the experience and measurement of time differ considerably for the world above (the sanatorium) and the world below (everyday bourgeois reality)."
}

Pandaemonium, São Paulo, v. 23, n. 40, mai.-ago. 2020, p. 1-19 
fundamentam tal realidade. Saliente-se, a esse respeito, que o trabalho formal realizado por Mann no que concerne ao tempo é, como assinala Michel Zéraffa (2010: 462), "o resultado de uma civilização incerta em si mesma e que procura ordenar-se no espaço e no tempo". Ora, a desorientação simbólica da humanidade nas primeiras décadas do século XX não seria análoga à desorientação temporal de Hans Castorp?

Assim entendemos porque, para o indivíduo em situações de exceção, passa a existir uma crise de valores capaz de transformar (ou mesmo de distorcer propositadamente) a própria percepção da realidade empírica. É, dentre outros exemplos, o que Jean-Paul Sartre tencionou emular em se tratando da Segunda Guerra Mundial, representada em seu romance Le Sursis, publicado em 1949. Nele encontramos uma narrativa fragmentada, simultânea e desorientadora tanto para as personagens como para o leitor, fazendo com que o romance seja capaz de sugerir a desorientação histórica que narra. No caso d'A montanha mágica, para além da técnica narrativa envolvida, é manifesto um memento constante do tempo, considerado enquanto desenrolar representativo e inexorável, seja por meio das discussões travadas pelas personagens, seja por meio de elementos narrativos que marcam o caminho temporal do protagonista, contando os dias, as semanas, os meses, os anos em que está ali. A lentidão do tempo percebido chega até mesmo a sugerir que, em determinados momentos, a desaceleração dá espaço a um movimento em sentido contrário, ou seja, em direção ao passado. $\mathrm{O}$ episódio em que o protagonista tem sua primeira lembrança sobre um colega de infância é paradigmático, quando, então, Hans Castorp se encontra

num estado de vitalidade singularmente diminuída; pois, cada vez que expelia o ar, durante algum tempo não experimentava nenhuma necessidade de aspirar outra vez; com o corpo em suspenso, deixava, com toda a calma, que seu coração palpitasse diversas vezes, antes que, tardia e indolentemente, voltasse a tomar fôlego.

Eis que, de súbito, sentiu-se transportado para aquela fase remota da sua vida, em que se passara a cena original de um sonho remodelado em conformidade com impressões mais recentes, e que tivera poucas noites atrás... Viu-se arrebatado para o lá e o outrora, sem deixar qualquer vestígio, a ponto de suspender o espaço e o tempo, e com tanto vigor que se poderia dizer que no banco junto da cachoeira jazia um corpo inânime, ao passo que o verdadeiro Hans Castorp se encontrava longe dali, num ambiente e numa época muito distantes - e ainda numa situação que, apesar da sua simplicidade, era para ele arriscada e lhe inebriava o coração. (MANN 2016: 141)

Essa redoma atemporal, todavia, será estilhaçada ao fim do romance, com o célebre e súbito trovão da guerra, quando "a irrupção do tempo histórico [...], de fora, fratura a prisão enfeitiçada" (RICEUR1995: 222, grifo no original), expelindo Hans Castorp para a planície. Se até então o sanatório de Berghof se mantivera apartado 
ABRAHÃO, T. H. C. - A liberdade em A montanha másica

espacial e simbolicamente do mundo, com o peso da desorientação histórica oriunda da guerra ocorre o fim do sequestro simbólico sofrido por Hans Castorp na montanha mágica. Como se ao acordar de um longo sono sem responsabilidade, o protagonista se depara com sua autonomia sociopolítica, abandonada (ou, talvez, nunca assumida) quando de sua partida para as alturas do sanatório. O trovão sugere também a libertação do protagonista das mãos do narrador, "esse mago que evoca o pretérito" (MANN 2016: 11), um pretérito cujos fatos ele controla e que, por isso, "é necessário que as histórias já se tenham passado, e quanto mais mergulhadas no passado, caberia dizer, melhor corresponderão à sua qualidade essencial de histórias, e mais adequadas serão ao narrador" (MANN 2016: 11).

A estrutura romanesca que acabamos de explorar brevemente em alguns de seus elementos espaciais, temporais e narrativos faz d'A montanha mágica um laboratório controlado no qual as personagens em interação estabelecem um ambiente polifônico, cuja técnica narrativa, empregada por Fiódor Dostoiévski e teorizada por Mikhail Bakhtin, abrange uma "multiplicidade de centros-consciências não reduzidos a um denominador ideológico" (BAKHTIN 2013: 17). Isso significa que a voz das personagens não é dominada pelo diapasão ideológico da voz narratorial; pelo contrário, têm espaço (e tempo) para fazer valer suas perspectivas idiossincráticas. Não há, pois, monopólio ideológico: o narrador não é $a$ voz, mas uma voz dentre as muitas que compõem esse universo romanesco. Em outras palavras, busca-se a horizontalização da voz narrativa no lugar de sua verticalização, cuja consequência direta é a hierarquização redutora das perspectivas de mundo ali representadas, como encontramos em romances cuja onisciência narratorial omite e julga sempre a seu favor. Nesse sentido, Joachim Ziemßen, Hofrat Behrens, Clawdia Chauchat, Lodovico Settembrini, Leo Naphta, Mynheer Peeperkorn e, evidentemente, Hans Castorp são, por conseguinte, porta-vozes de visões de mundo, representantes de modos de ser diferentes, divergentes e, por vezes, contraditórios.

Em se tratando da liberdade, poderíamos separar as personagens em dois grandes grupos a representarem, no que diz respeito à permanência do protagonista no sanatório, ou uma força de atração (destino, determinismo) ou de repulsão (liberdade). Assim, se de um lado temos Hofrat Behrens, por sua posição de médico e diretor do estabelecimento, e Clawdia Chauchat, por seduzir o jovem, como exemplos de forças que o mantêm na 
montanha, de outro lado Settembrini, por meio da razão, e Joachim, a partir da emoção, são forças que o repelem e tentam fazê-lo ir embora.

São as forças contrárias do mundo histórico-social, são as dificuldades que se impõem para o indivíduo em sua existência cotidiana que servem de contrapeso e emprestam valor à sua liberdade, cujos limites precisam ser traçados para que ela seja perceptível. Afinal, a liberdade sem algum limite não seria liberdade, mas niilismo, posto que toda escolha, desde que livre, é embasada em valores escolhidos autonomamente. Ademais, no seio do processo dialético entre o indivíduo e a sociedade está o motor que quebra a inércia da identidade e a faz se transformar. Em outras palavras, "é justamente a oposição entre um homem e seu ambiente que determina o desenvolvimento de sua personalidade" (LUKÁCS 1969: 28), o que, no caso de Hans Castorp, se dá em meio a um variado corpus de visões de mundo, algumas intelectualmente doentias, outras doentiamente intelectuais, cujas "consequências psicológicas e morais não são teoremas abstratos [...], mas crescem orgânica e diretamente das vidas física, mental e emocional das pessoas que vivem lá"9 (LUKÁcs 1979: 34-35). Mais do que isso, crescem do fato, também partilhado pelo leitor em seu mundo extraliterário, de que a liberdade existe para além de uma existência meramente teórica, pois surge da coexistência de subjetividades numa conjuntura histórica específica, na qual ninguém pode saber $o$ que os outros pensam ou como, quando e por que pretendem agir. Os outros, subjetividades opacas, fazem parte de nossa liberdade assim como nós fazemos parte da deles, pois, desnecessário dizer, as ações e suas consequências repercutem para além de seus atores. Não obstante, o índice de liberdade que para nós é o outro - cujas ações não podemos prever com certeza - é mantido e reforçado pelo índice de liberdade que, por vezes e repentinamente, somos nós para nós mesmos.

Como na existência concreta do leitor, as personagens são índices de liberdade umas para as outras e para si mesmas, participando da liberdade que somos - ou que, por algum motivo, não podemos ser. Este último é o caso do protagonista d'A montanha mágica: Hans Castorp é, segundo o próprio autor, "um herói simples"10 (MANN 1958: 11), mas que "no febril hermetismo da montanha mágica [...] passa por uma ascensão que o

\footnotetext{
8 "it is just the opposition between a man and his environment that determines the development of his personality."

9 "their psychological and moral consequences are not abstract theorems [...], but grow organically and directly out of the physical, mental and emotional lives of the people living there."

10 "Ein simpler Held".

Pandaemonium, São Paulo, v. 23, n. 40, mai.-ago. 2020, p. 1-19
} 
torna apto a aventuras morais, espirituais e sensuais"11 (MANN 1958: 16), as quais lhe permitirão uma formação completa a respeito do que é a liberdade - que se dá, portanto, e repetindo, num ambiente paradoxal em que o ser livre torna-se enfraquecido, desorientado. Veja-se o caso mais evidente da desorientação temporal que a personagem começa a sentir ao longo dos primeiros dias, a ponto de, posteriormente, estar num estágio tão avançado que já sente dificuldade de se lembrar de sua própria idade.

Hans Castorp se encontra, pois, num laboratório existencial que começará a lhe despertar interesse sobre assuntos distantes da exatidão de seu mundo profissional matemático. Temos, dentre muitos exemplos, sua experiência a respeito da (própria) morte ao longo do quinto capítulo, em que o protagonista vê pela primeira vez, não de relance, mas diretamente, um agonizante: "Era o primeiro moribundus com que Hans Castorp deparava em sua vida, visto os pais e o avô terem morrido, por assim dizer, pelas suas costas” (MANN 2016: 126). Essa aproximação com a morte continua pelos demais subcapítulos: em "Pesquisas", Hans Castorp passará por um aprendizado teórico em relação à fisiologia humana; em "Dança macabra", por um exercício prático oriundo dos encontros premeditados com alguns enfermos em estágio terminal; em "Sopa eterna e clareza repentina", por um aprendizado sobre o processo que é a existência humana livre até o destino cego de seu colapso; em “Meu Deus, eu vejo!", por uma apreensão íntima sobre a própria morte ao observar sua mão através do radioscópio, mostrando-lhe a parte viva, pulsante e perecível de seu ser:

E Hans Castorp viu o que devia ter esperado, mas que, em realidade, não cabe ver ao homem, e que jamais teria crido poder ver: lançou um olhar para dentro do seu próprio túmulo. Viu, antecipado pela força dos raios, o futuro trabalho da decomposição; viu a carne em que vivia, solubilizada, aniquilada, reduzida a uma névoa inconsistente, em meio à qual se destacava o esqueleto minuciosamente plasmado da sua mão direita, e em torno da primeira falange do dedo anular pairava, preto e frouxo, o anel-sinete que o avô lhe legara, um objeto duro desta terra, com o qual os homens adornam esse seu corpo destinado a desfazer-se, para que ele, o objeto, fique novamente livre e se possa enfiar em outra mão que o use durante algum tempo. Com os olhos daquela parenta da família Tienappel, contemplou uma parte familiar do seu corpo, estudou-a com olhos videntes e penetrantes, e pela primeira vez na vida compreendeu que estava destinado a morrer. (MANN 2016: 253-254)

Seja a morte, seja o tempo, seja a liberdade, seja qualquer outro elemento formador do quebra-cabeça existencial que é o homem, tudo será objeto de reflexão por parte do protagonista. Suas pesquisas e interrogações sobre o estranho mundo do

\footnotetext{
11 "In der fieberhaften Hermetik des Zauberberges aber erfährt dieser schlichte Stoff eine Steigerung, die ihn zu moralischen, geistigen und sinnlichen Abenteuern fähig macht".

Pandaemonium, São Paulo, v. 23, n. 40, mai.-ago. 2020, p. 1-19
} 
sanatório são nutridas pela convivência com os internos, entre os quais se destaca Lodovico Settembrini. Esse italiano, defensor inveterado da razão e do progresso, apresenta uma perspectiva crítica a respeito dos habitantes da montanha, fauna que encarnaria, para ele, o contrário de seu ideal de humanidade cultural e historicamente viva. As reflexões do intelectual, pautadas em suas convicções humanistas - "sou humanista, um Homo humanus" (MANN 2016: 74) -, servem como contra-argumento ao mundo simbólico, encantado e sem liberdade de Berghof. Lodovico Settembrini, em contraste, provém de uma linhagem de humanistas defensores da liberdade: o avô era “não [...] somente um patriota italiano, senão também um concidadão e um irmão em armas de todos os povos sedentos de liberdade"; o pai, por sua vez, "não renunciara ao direito de concitar a nação [...] à liberdade e à instauração da república unida, [...] e de proclamar num estilo claro a unificação dos povos libertos em prol da felicidade universal” (MANN 2016: 178-179). Por suas ideias e por suas roupas puídas (diferentemente dos internos, sempre bem vestidos), o italiano destoa do ambiente do sanatório, fazendo de sua presença um índice de liberdade para Hans Castorp e representando, desde o início, uma força contrária à permanência do protagonista no sanatório: o intelectual italiano, enquanto liberdade esclarecida, insiste em convencer Hans Castorp - esse "filho enfermiço da vida" (MANN 2016: 355) - a voltar para a planície, para a sociedade, para o meio das comunicações e das trocas simbólicas, do convívio e da tolerância, da liberdade e da justiça:

Seja orgulhoso e não se perca no ambiente estranho! Evite este atoleiro, esta ilha de Circe. O senhor não é Ulisses tanto assim, para habitá-la impunemente. Acabará andando sobre as quatro patas, já está a ponto de se apoiar nas extremidades dianteiras, e daqui a pouco começará a grunhir. Cuidado! (MANN 2016: 285)

Ou em cena posterior:

Caro amico! Será necessário tomar decisões, decisões de importância inestimável para a felicidade e o futuro da Europa, e elas caberão ao seu país. Situado entre o Oeste e o Leste, terá de escolher, terá de declarar-se definitiva e conscientemente por uma ou outra das duas esferas que lhe disputam a natureza. O senhor é jovem. O senhor participará dessa decisão, sua vocação é influir sobre ela. Bendigamos, pois, o destino. Se ele o arrastou até estas paragens medonhas, ao mesmo tempo deu-me a oportunidade de exercer certa influência sobre sua juventude maleável, por meio de minhas palavras, não totalmente isentas de experiência e vigor: a oportunidade de fazer sua juventude sentir a responsabilidade que pesa sobre ela, ou melhor, que sua pátria traz sobre os ombros, ante toda a civilização... (MANN 2016: 594)

Em contrapartida temos Leo Naphta, jesuíta reacionário e crítico dos ideais iluministas. Ele trava, com o intelectual italiano, intensos e complexos debates 
acompanhados por Hans Castorp e que ajudam o jovem engenheiro a compreender ideias como a liberdade:

Que o Renascimento deu à luz tudo aquilo que se chama liberalismo, individualismo, humanismo burguês é um fato que eu conhecia mais ou menos bem. [...] Mas, se acredita que o resultado das revoluções vindouras será a liberdade, iludiu-se redondamente. $\mathrm{O}$ princípio da liberdade cumpriu o seu destino e chegou a ser antiquado nos últimos quinhentos anos. Uma pedagogia que ainda hoje pretende ser a filha do racionalismo e vê os seus meios formativos na crítica, na libertação e no culto do eu, na destruição de formas de vida determinadas de um modo absoluto, ora, tal pedagogia pode obter ainda hoje triunfos retóricos passageiros, porém o seu caráter atrasado é óbvio para os espíritos avisados. Todas as organizações verdadeiramente educadoras sempre souberam qual deve ser o objetivo último da pedagogia, afinal: a autoridade absoluta, a obrigação de ferro, a disciplina, o sacrifício, a renúncia a si próprio, o domínio da personalidade. Em última análise, desconhece e não ama a juventude quem pensa que ela sente prazer diante da liberdade. O que ela aprecia mais é a obediência. (MANN 2016: 461)

Curiosamente, a cena transcrita, cujo tema principal é exatamente a liberdade, serve como início para uma desinteligência que dará espaço a um duelo entre os intelectuais - ocasião em que, de arma na mão, Leo Naphta apertará o gatilho contra a própria cabeça, empregando sua liberdade para destruí-la e agindo, ao menos, com fidelidade aos seus valores. Diante dessa cena, "Castorp verá a vitória do absurdo, a derrota do espírito que sucumbiu à tentação do absoluto (como o corpo sucumbe à tuberculose) em vez de se ultrapassar por um supremo esforço de racionalidade" (ZÉRAFFA 2010: 256).

Destino parecido, embora não pelos mesmos meios, terá Joachim Ziemßen. Quando da chegada do primo para visitá-lo no sanatório, ele já se encontra internado há cinco meses, necessidade médica que sobrepujou seu desejo de ingressar no exército: "Um ano tem tanta importância na nossa idade, traz tantas alterações e tantos progressos na vida lá de baixo! E eu obrigado a estagnar aqui como uma poça d'água, sim senhor, como um charco apodrecido" (MANN 2016: 27). Sua ideia fixa de voltar para a planície e prosseguir com seu sonho faz com que ele resolva ir embora, a despeito das recomendações médicas e com uma atitude revolucionária diante do mundo de fraca liberdade que é a montanha. O jovem aspirante a oficial tem um objetivo, uma escolha, uma responsabilidade que quer assumir ante sua luta particular por sua liberdade em sursis no sanatório. Contrariamente à mente teorizadora do primo engenheiro, Joachim Ziemßen é um espírito prático cuja liberdade de pensamento é nula enquanto não coexiste com sua liberdade de escolha:

- Ah, meu caro, aqui em cima você está cada vez mais inteligente, com sua biologia e botânica, e com os seus pontos de inflexão inevitáveis. E desde o primeiro dia se

Pandaemonium, São Paulo, v. 23, n. 40, mai.-ago. 2020, p. 1-19 
preocupou com o "tempo". Mas me parece que estamos aqui para ficar mais sadios e não mais sábios; mais sadios e completamente sãos, até que enfim nos devolvam a liberdade e nos enviem à planície como curados.

- "A liberdade vive nas montanhas!" - cantarolou Hans Castorp, frivolamente. Primeiro, diga-me o que a liberdade é! - acrescentou, falando. - Naphta e Settembrini também discutiram isso e não chegaram a um acordo. (MANN 2016: 445-446, grifo meu)

Fato é que Hans Castorp, apesar de entrar em contato com a palavra e seu conceito, desconhece, intencionalmente ou não, a liberdade. Ora, o protagonista nunca se deparou com a necessidade de tomar grandes decisões na planície. Quando necessário, outros escolhiam por ele, como no caso de sua profissão: forma-se em engenharia naval "obedecendo a uma sugestão do velho Wilms [amigo da família]" (MANN 2016: 46).Quanto à sua permanência no sanatório, a seguir o meticuloso horário de refeições, repousos e exames, duas forças agem para tal. Hofrat Behrens, por um lado, é uma força racional que decide por Hans Castorp - "Nada melhor, no seu caso, do que viver por algum tempo como se tivesse uma ligeira tuberculosis pulmonum e acumular proteínas" (MANN 2016: 60) -, o que é aceito passivamente pelo protagonista até o momento em que, mesmo tendo alta, a inércia existencial a que chegou o prende na montanha.

Por outro lado, Clawdia Chauchat, força ligada ao âmbito emocional, faz com que o jovem apaixonado a espere por anos na montanha. Essa jovem e estranha mulher, figura da indisciplina, apresenta um comportamento inconsequente representado pelos estrondos que causa ao bater a porta envidraçada do refeitório: "De repente, Hans Castorp sobressaltou-se, irritado e ofendido. Uma porta acabava de bater violentamente [...]. Escapara às mãos de alguém ou fora mesmo fechada com força” (MANN 2016: 58). Clawdia Chauchat tem papel decisivo na vida do protagonista por ser a figura dúbia da morte, com seus vestidos negros e suas chegadas repentinas, e do amor, por seduzir Hans Castorp. Uma das cenas centrais dessa relação ocorre no dia do Carnaval, quando da primeira conversa deles. A mulher, “[e]m nome da liberdade própria das máscaras, tratouo por você" (MANN 2016: 375). Some-se à informalidade o fato de o diálogo não ocorrer apenas em alemão, pois há frases trocadas também em língua francesa, como esta, do protagonista: “eu, tu observas bem, quase não falo francês. Contudo, contigo prefiro essa língua à minha, pois, para mim, falar francês é falar sem falar, de qualquer forma: sem responsabilidade"12 (MANN 2016: 388). Vê-se também uma "máscara linguística" empregada pelos dois - máscara que, como as literais, eximem as personagens de parte

\footnotetext{
12 "Moi, tu le remarques bien, je ne parle guère le français. Pourtant, avec toi je préfère cette langue à la mienne, car pour moi, parler français, c'est parler sans parler, en quelque manière : sans responsabilité".
}

Pandaemonium, São Paulo, v. 23, n. 40, mai.-ago. 2020, p. 1-19 
da responsabilidade que carregariam se não estivessem com parte de sua identidade (e de suas intenções) oculta. Nessa conversa, o jovem descobre que Clawdia Chauchat partirá no dia seguinte, pois, diz ela, "eu amo a liberdade antes de tudo [...]. Tu quase não compreendes o que é: ser obcecado pela independência"13 (MANN 2016: 409).

A dependência de Hans Castorp, ao contrário, o faz permanecer em Berghof durante sete anos, período ao longo do qual o protagonista frequentou todas as sete mesas do refeitório e aguardou, todos os dias, os sete minutos de espera com o termômetro na boca. Esse tempo objetivo, contudo, é mais importante para o leitor do que para o protagonista, cujo desprezo para com o passar das horas fica explícito ao fim do romance: “o relógio de algibeira. Estava parado, pois certo dia caíra da mesinha de cabeceira, e ele não tratara de mandar consertá-lo para que reassumisse sua cadenciada marcha circular" (MANN 2016: 819). Essa liberdade do protagonista, que o narrador insiste em afirmar, é patente. Não se trata, como sabemos, da liberdade como entendemos neste estudo, mas de uma liberdade como fim em si, não como meio de existir - o que significa, simplesmente, não liberdade. No subcapítulo curiosamente intitulado "Liberdade", quando Hans Castorp despacha uma carta para um familiar na planície, isso fica claro:

Assinou. Estava feito o trabalho. Essa terceira carta esgotava o assunto e teria um efeito duradouro - não segundo os conceitos de tempo que reinavam lá embaixo, mas segundo os daqui de cima; ela consolidava a liberdade de Hans Castorp. Foi essa a palavra que empregou, não expressamente, e sem formar sequer as sílabas em seu íntimo, mas sentindo-lhe o significado mais amplo, como aprendera a fazer durante sua estada aqui significado que pouco tinha que ver com o que Settembrini dava à palavra. (MANN 2016: 273, grifo no original)

Sua existência inercial por sete anos confirma a afirmação de que "A montanha mágica é uma epopeia das premissas da ação social no mundo de hoje. A aventura de Castorp engloba [...] o conteúdo e a forma da escolha que deve preceder toda ação"14 (LUKÁCS 1979: 119-120, grifo meu). Todavia, a problemática se intensifica se pensarmos que, entre o amor e o ódio, entre a vida e a morte, entre a liberdade e o destino, Hans Castorp assiste ao fracasso daqueles que tentaram ser livres: seu primo, comprometido com a carreira militar, morre após complicações médicas oriundas do abandono de seu tratamento; Lodovico Settembrini, comprometido com a redação do verbete de uma enciclopédia, tem seus planos malogrados por causa da doença; Leo Naphta, comprometido com ideias radicais, se suicida; Mynheer Peeperkorn - personagem que

\footnotetext{
13 “j'aime la liberté avant tout [...]. Tu ne comprends guère ce que c'est : être obsédé d'indépendance."

14 "The Magic Mountain is an epic of the premises of social action in the world of today. Castorp's adventure encompasses [...] the content and form of the choice which must precede all action."
}

Pandaemonium, São Paulo, v. 23, n. 40, mai.-ago. 2020, p. 1-19 
surge como um novo pedagogo na vida de Hans Castorp, instruindo-lhe por um viés hedonista da vida -, também encontra a morte no suicídio. Para além de tais exemplos, o estrondo de um trovão

de que todos temos ciência, essa detonação ensurdecedora da mistura sinistra de tédio e irritação há muito acumulados: um trovão histórico, diga-se com discreta reverência, que abalou os alicerces da Terra; e o trovão que, para nós, porém, faz explodir a montanha mágica e lança ante seus portões, insuavemente, o nosso dorminhoco. (MANN 2016: 819)

É quando a história cobra, enfim, a responsabilidade daquela consciência há muito exilada, algo diferente, mas ainda incapaz de ser livre. Ora, antes de partir do próprio protagonista a iniciativa de voltar para a planície, são os fatos históricos que, por sua vez e gravidade, alcançam o topo da montanha e puxam a personagem de seu sono: "Viu-se desencantado, redimido, libertado - não a partir da força que era sua, como teve que admitir com certa vergonha, senão expulso por potências exteriores e elementares" (MANN 2016: 822). Nesse sentido, ao descer da montanha e se encontrar nas fileiras do exército, Hans Castorp não está mais à sombra de ninguém, é "a figura de uma testemunha, isto é, a de uma impotência" (ZÉRAFFA, 2010: 260). Seu futuro é devolvido, um futuro que, enquanto tal, é incerto para ele e também para o leitor.

Suas perspectivas não são boas; o macabro baile ao qual o arrastaram ainda vai durar uns vários anos de pecados, e não queremos apostar muita coisa em que você vai escapar. Para falar com franqueza, não sentimos escrúpulos por deixar aberta essa questão. Certas aventuras da carne e do espírito, que sublimaram sua singeleza, fizeram seu espírito sobreviver ao que sua carne dificilmente sobreviverá. Momentos houve em que, cheio de pressentimentos e absorto em seu reinar, você viu brotar da morte e da luxúria do corpo um sonho de amor. Será que também dessa festa mundial da morte, e também da perniciosa febre que inflama o céu da noite chuvosa, ainda surgirá o amor? (MANN 2016: 827)

Nessa interrogação do parágrafo final, encontramos um índice de liberdade a demandar que o leitor complete essa lacuna premeditada na vida futura do protagonista. Não obstante, insinua para o leitor a tarefa de, fechado o livro, compreender a realidade sócio-histórica para a qual este retornará.

O que artistas como Thomas Mann se esforçam para nos apresentar é uma problemática, não uma resposta. Nesse sentido, quisemos apresentar como a obra do escritor alemão se insere no contexto histórico de sua produção, atraindo para si uma responsabilidade estética que é, também, ética. N'A montanha mágica, particularmente, vimos como uma ideia de liberdade é sugerida por meio do próprio narrar, discutida e representada nas entrelinhas enquanto um pilar essencial para a criação ficcional - e para a existência humana, contemplada como pano de fundo. As personagens de Berghof, 
ABRAHÃO, T. H. C. - A liberdade em $A$ montanha mágica

consciências de autonomia duvidosa, estabelecem-se e se organizam no tempo e no espaço narrativo de um sanatório que atenua e uniformiza a autonomia individual.

Por esse viés, os perigos pelos quais passou Hans Castorp não são tão diferentes dos perigos que encontramos nas grandes civilizações atuais. As novas tecnologias, a aceleração cada vez mais desumana do tempo, a ausência de valores capazes de dar sentido à existência presente são ameaças que, por distorcerem a compreensão sobre o que é a liberdade, colocam em xeque a autonomia crítica do indivíduo, trancam-no numa redoma ideológica e conferem-lhe a inércia própria do senso comum. Vale lembrar que a atenuação e a uniformização da reflexão autônoma dizem respeito a um fenômeno representativo de contextos sócio-históricos igualmente uniformes e entorpecidos, tratando-se, inevitavelmente, de uma ameaça para o avanço da vida individual e coletiva. Ora, entre a excelência e a excrescência do mundo humano, sempre haverá alguma elevação, mágica ou não, da qual precisaremos descer para também enfrentar nossa planície.

\section{Referências bibliográficas}

Bakhtin, M. Problemas da poética de Dostoiévski. 5. ed. Tradução: Paulo Bezerra. Rio de Janeiro: Forense Universitária, 2013.

Coutinho, N. C. Lukács, Proust e Kafka: literatura e sociedade no século XX. Rio de Janeiro: Civilização Brasileira, 2005.

DAYAN-HerzBrun, S. Thomas Mann, um escritor contra o nazismo. Trans/Form/Ação, São Paulo, v. 20, 1997, p. 71-86.

LUKÁCS, G. The meaning of contemporary realism. Tradução: John Mander, Necke Mander. London: Merlin Press, 1969.

LuKÁCS, G. Essays on Thomas Mann. Tradução: Stanley Mitchell. London: Merlin Press, 1979.

MAGRIS, C. O romance é concebível sem o mundo moderno? In: MoReTti, F. A cultura do romance. São Paulo: Cosac Naify, 2009, p. 1013-1028.

MANN, T. Betrachtungen eines Unpolitischen. Berlin: S. Fischer, 1918.

Mann, T. Das Problem der Freiheit. Stockholm: Bermann-Fischer, 1939.

MANN, T. Doktor Faustus: das Leben des deutschen Tonsetzers Adrian Leverkühn, erzählt von einem Freunde. Stockholm: Bermann-Fischer, 1947.

MANN, T. Einführung in den Zauberberg. Für Studenten der Universität Princeton. In: MANN, T. Der Zauberberg. Frankfurt: S. Fischer Verlag, 1958.

MANN, T. A montanha mágica. Tradução: Herbert Caro. São Paulo: Companhia das Letras, 2016.

Nietzsche, F. O nascimento da tragédia ou Helenismo e pessimismo. 2. ed. Tradução: J. Guinsburg. São Paulo: Companhia das Letras, 1999.

REED, T. Thomas Mann: the uses of tradition. Oxford: Clarendon, 1974.

RICEUR, P. Tempo e narrativa. v. 2. Tradução: Marina Appenzeller. Campinas: Papirus, 1995.

SARTRE, J.-P. Le sursis. Paris: Gallimard, 1949.

Pandaemonium, São Paulo, v. 23, n. 40, mai.-ago. 2020, p. 1-19 
ABRAHÃO, T. H. C. - A liberdade em A montanha mágica

Vogel, H. Die Zeit bei Thomas Mann: Untersuchungen zu den Romanen Der Zauberberg. Kiel: Joseph und Faustus, 1970.

ZÉRAFFA, M. Pessoa e personagem: o romanesco dos anos 1920 aos anos de 1950. Tradução: Luiz João Gaia, J. Guinzburg. São Paulo: Perspectiva, 2010.

Recebido em 6 de julho de 2019

Aceito em $1^{\circ}$ de outubro de 2019

Pandaemonium, São Paulo, v. 23, n. 40, mai.-ago. 2020, p. 1-19 